\title{
Flatwise Compression Strength and Energy Absorption of Polyurethane Foam Filled Lattice Core Sandwich Panels
}

\author{
Y. Rostamiyan ${ }^{1}$ and H. Norouzi \\ Department of Mechanical Engineering, Sari Branch, Islamic Azad University, Sari, Iran \\ ${ }^{1}$ yasser.rostamiyan@iausari.ac.ir
}

УДК 539.4

\section{Прочность при сжатии и энергия поглощения многослойных панелей с наполнителем из полиуретановой пены}

\section{Я. Ростамиян, Х. Нороузи}

Исламский университет Азад, Сари, Иран

Исследовано влияние наполнителя из полиуретановой пены на прочность и энергопоглощение ячеистых многослойных панелей при сжатии. Испытания на сжатие показывают, что несущая способность ячеистых многослойных панелей с наполнителем из полиуретановой пены выше, чем таковая таких панелей без наполнителя, либо образцов, состоящих только из полиуретановой пены. Эффективность энергопоглощения образиов с более высокой относительной плотностью ячеек (5,1 и 5,7\%) оказалась ниже, чем образиов без наполнителя при низких уровнях деформации сжатия, однако по достижении последней уровня 0,1 и выше имеет место ярко выраженный обратный эффект. При этом энергопоглощение образиов с меньшей относительной плотностью ячеек (4,43\%) выше, чем образцов без наполнителя.

Ключевые слова: многослойная панель, сердцевина решетки, полиуретановая пена, механические свойства, эффективность поглощения энергии.

Introduction. Super-lightweight sandwich panel structures attract much attention of researchers due to their desirable efficiency and high level of building energy absorption [1-4]. These structures are widely used in aerospace and submarine industries. Sandwich structures have recently been developed with different combinations of surface and core plates, in order to improve their performance. These structures contain lightweight and robust surface plates [5] and dense cell cores made of metallic foams [6, 7] and honeycomb cores [8-12] from polymers such as Nomex [13-16], while networked trusses are made with light metals such as aluminum [17-20] and titanium alloys [21, 22].

The outstanding interest that exists for sandwich structure application with foam cores in industrial fields seems to be very topical. Foam cores can play the role of structural equipment, cooling machine or acoustic dissipater [23]. For this purpose, rigid and light materials are used to make sandwich structures. Sandwich panel structures made up of carbon fiber-reinforced polymer (CFRP) are significantly linked to the recent studies [24-28]. Various networks of such structures can be made using the hot press molding [24, $25]$ or snap fit methods $[18,27]$; therefore, they are used to produce honeycomb structures [26].

Therefore, the primary aim of this study was to achieve a high compressive strength by changes in the honeycomb core designs. Another aim of the study was to apply the polyurethane foam injected into honeycomb cores, in order to raise the peak of compressive strength and to compare the performance of foam-filled cores with unfilled ones. 


\section{Specimen Fabrication.}

1.1. Composite Laminate Material. In this study, the laminate sheets were fabricated from 14 layers of unidirectional carbon fiber/epoxy resin prepreg sheets (T300/ epoxy composited, $\rho_{s}=1760 \mathrm{~kg} / \mathrm{m}^{3}$ ) with a thickness of $0.17 \mathrm{~mm}$ (as shown in Tables 1 and 2) by vacuum-assisted resin transfer molding (VARTM) method (Fig. 1) which is the best method for minimizing the laminate porosity. Also, all laminates thickness was $2.8 \mathrm{~mm}$.

$\mathrm{T}$ a b 1 e 1

Properties of Plain Carbon Fiber Sheets (T300)

\begin{tabular}{|c|c|c|c|}
\hline $\begin{array}{c}\text { Density } \\
\left(\mathrm{kg} / \mathrm{m}^{3}\right)\end{array}$ & $\begin{array}{c}\text { Tensile strength } \\
(\mathrm{MPa})\end{array}$ & $\begin{array}{c}\text { Tensile modulus } \\
(\mathrm{GPa})\end{array}$ & $\begin{array}{c}\text { Strain } \\
(\%)\end{array}$ \\
\hline 1760 & 3500 & 230 & 1.5 \\
\hline
\end{tabular}

T a b 1 e 2

Properties of Epoxy Resin and Hardener

\begin{tabular}{||c|c|c|c|c|c||}
\hline \hline Material & $\begin{array}{c}\text { Commercial } \\
\text { name }\end{array}$ & $\begin{array}{c}\text { Viscosity } \\
\text { at } 25^{\circ} \mathrm{C} \\
(\mathrm{mPa} \cdot \mathrm{s})\end{array}$ & $\begin{array}{c}\text { Initial mixture } \\
\text { viscosity at } 25^{\circ} \mathrm{C} \\
(\mathrm{mPa} \cdot \mathrm{s})\end{array}$ & $\begin{array}{c}\text { Pot life } \\
\text { at } 25^{\circ} \mathrm{C} \\
(\mathrm{min})\end{array}$ & $\begin{array}{c}\text { Density } \\
\text { at } 25^{\circ} \mathrm{C} \\
(\mathrm{g} / \mathrm{ml})\end{array}$ \\
\hline Resin & EC $130 \mathrm{LV}$ & $1.2-1.6$ & $500-800$ & $95-117$ & $1.14-1.16$ \\
\hline Hardener & W340 & $45-55$ & & & $0.92-0.94$ \\
\hline
\end{tabular}

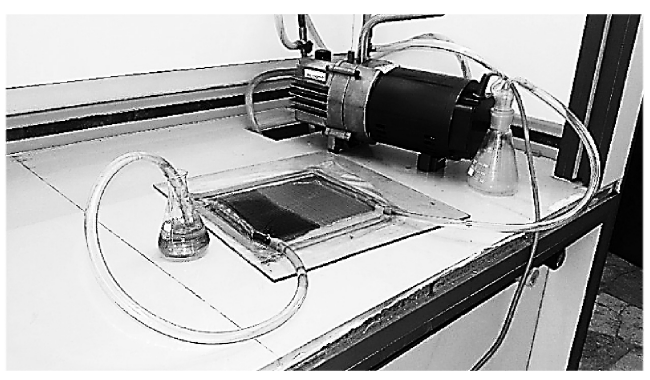

Fig. 1. VARTM method setup.

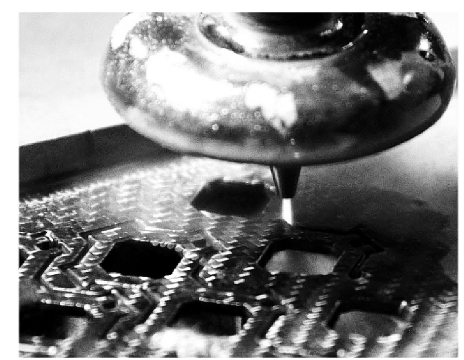

Fig. 2. Pattern of water-jet cutting from the laminate sheets.

After the end of the VARTM processing the laminate was subjected to room temperature for $12 \mathrm{~h}$. Then, these specimens were subjected to $60^{\circ} \mathrm{C}$ temperatures for $15 \mathrm{~h}$.

1.2. Fabrication of Sandwich Panels with Lattice Cores. The lattice sandwich panels were manufactured from $0 / 90^{\circ}$ laminate sheets of thickness $t=2.8 \mathrm{~mm}$ by a three-step procedure. Briefly, patterns as shown in Figs. 2 and 3 were water-jet-cut from the laminate sheets. Then, these patterns were snap-fitted into each other (Fig. $3 b$ ) to produce a lattice core. Finally, the lattice was bonded to $2.8 \mathrm{~mm}$ thick composite face sheets using an epoxy adhesive (Fig. $3 \mathrm{c}$ and d). The cure cycle consisted of $12 \mathrm{~h}$ at room temperature, followed by heating to $40^{\circ} \mathrm{C}$ for $3 \mathrm{~h}$. The critical parameters describing the geometry of the core are sketched in Fig. 4.

1.3. Fabrication of Polyurethane Foam-Filled Lattice Core Sandwich Panels. In the present study, the foam material consists of four-part polyurethane foam precursors in the form of liquid supplied by the Mokarrar Company (Mokarrar Industrial Group Co. Iran). Part A is polyol, part B is catalyst, part C is etan gas, and part D is isocyanate. When parts 


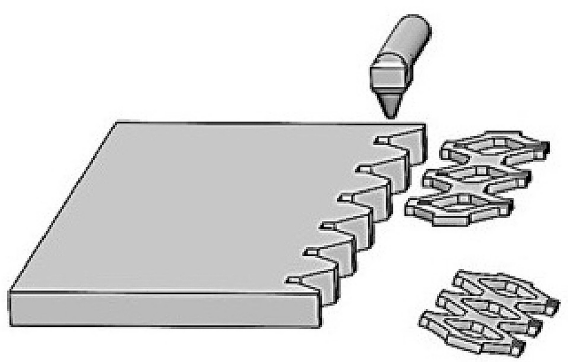

a

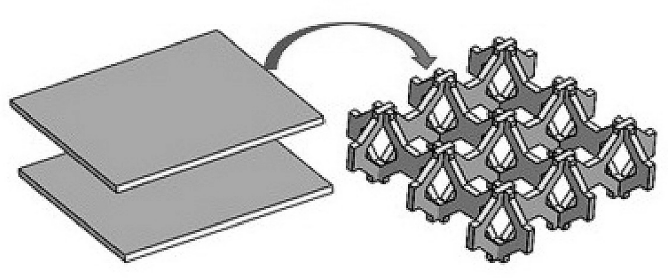

$\mathrm{c}$

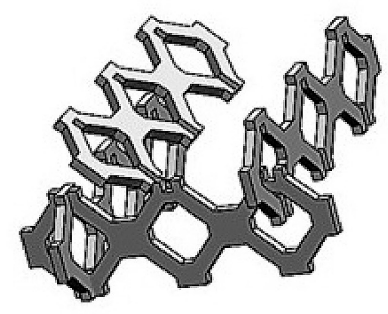

b

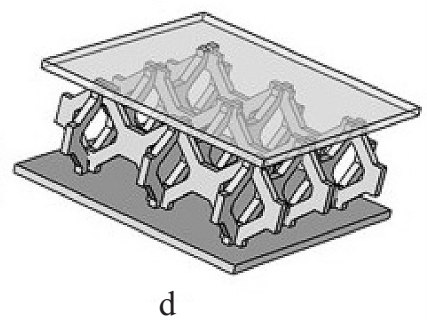

Fig. 3. Schematic of the manufacturing process of the carbon fiber lattice core sandwich structures: (a) cut continuous snap-fit truss patterns; (b) assemble the lattice core; (c) bond the lattice cores with facesheets; (d) the fabricated sandwich structure with lattice core.

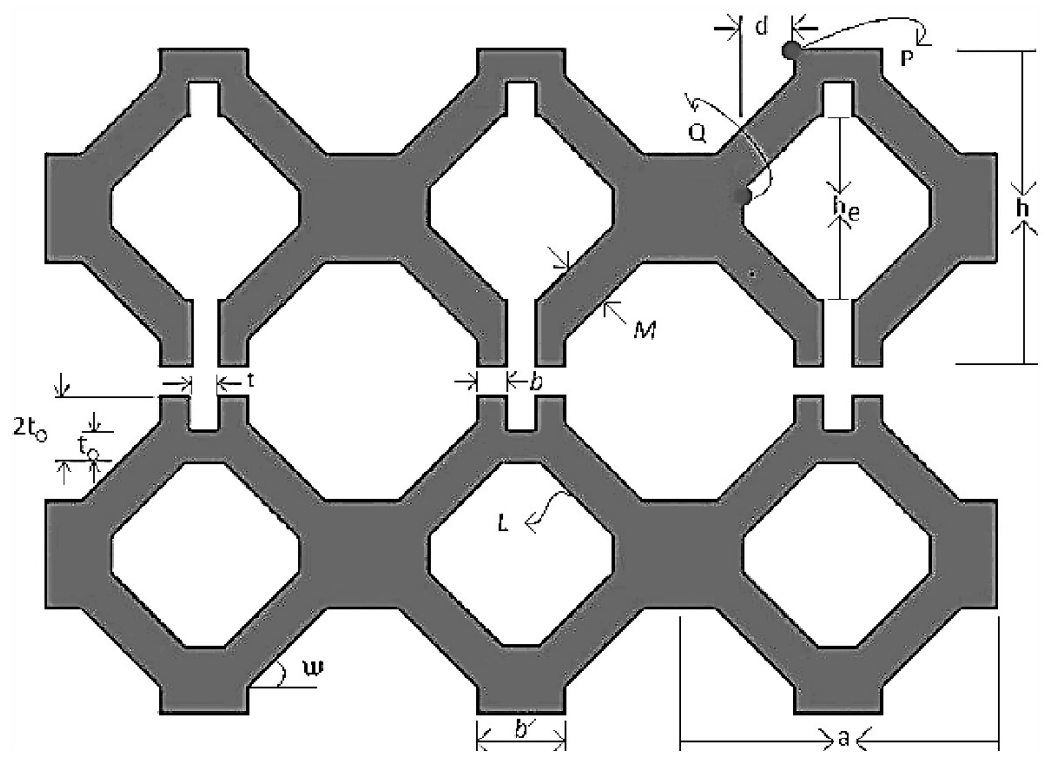

Fig. 4. Geometry of the lattice pattern with relevant core design variable.

$\mathrm{A}, \mathrm{B}, \mathrm{C}$, and $\mathrm{D}$ are mixed, heat is generated as a result of the polymerization reaction between the isocyanate and polyol; the resulting heat gives rise to the volatile liquid blowing agents to evaporate and form gas bubbles, which expands the mixture to produce foam. The process of filling the polyurethane foam to the lattice core sandwich panels is carried out in two steps. At the first step, parts A, B, and C are mixed with part D using a high-speed stirrer at about $1500 \mathrm{rpm}$. The mixing ratios of parts $\mathrm{A}, \mathrm{B}, \mathrm{C}$, and $\mathrm{D}$ are 44.4, $1.32,5.32$, and $48.7 \mathrm{wt} . \%$, respectively. Finally, the fabricated filled sandwich specimen is shown in Fig. 5b. The fabricated foam in the present study has a density of $80 \mathrm{~kg} / \mathrm{m}^{3}$. 


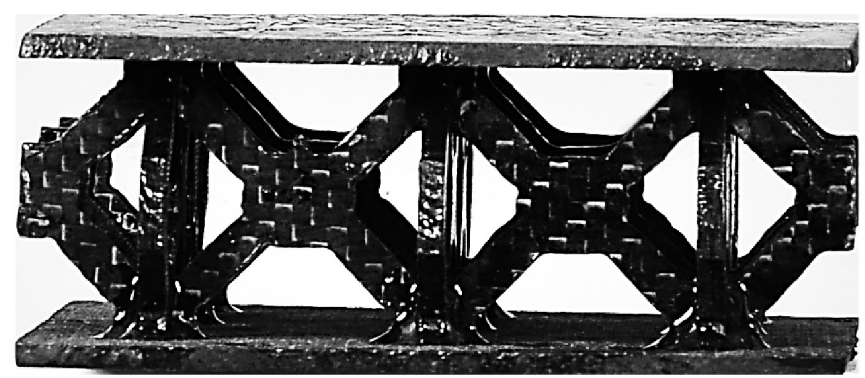

a

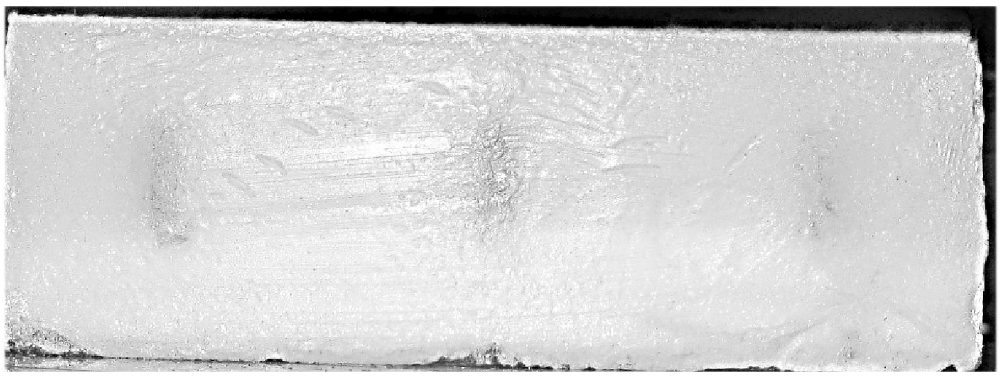

b

Fig. 5. Lattice core sandwich panel: (a) unfilled specimen; (b) foam-filled specimen.

\section{Flatwise Compressive Tests of Polyurethane Foam and the Foam-Filled Lattice} Core Sandwich Panels. All the honeycomb cores tested and manufactured in this study have a strut angle $\omega=45^{\circ}$ and all the cores have a strut thickness $t=2.8 \mathrm{~mm}$, node width $t=2.8 \mathrm{~mm}$, core height $h=30 \mathrm{~mm}$, whereas $t_{0}=0.8 M$ and the seat width values $b$ and $b^{\prime}$ were varied to enable manufacturing of cores of different mechanical responses, which are listed in Table 3.

$\mathrm{T}$ a b 1 e 3

The Lattice Core Parameters

\begin{tabular}{|c|c|c|c|c|c|c|c|c|c|c||}
\hline $\begin{array}{c}\text { Core } \\
\text { ID }\end{array}$ & $\begin{array}{c}\omega, \\
\text { deg }\end{array}$ & $\begin{array}{c}h, \\
\mathrm{~mm}\end{array}$ & $\begin{array}{c}h_{e}, \\
\mathrm{~mm}\end{array}$ & $\begin{array}{c}t, \\
\mathrm{~mm}\end{array}$ & $\begin{array}{c}b, \\
\mathrm{~mm}\end{array}$ & $\begin{array}{c}b^{\prime}, \\
\mathrm{mm}\end{array}$ & $\begin{array}{c}t_{0}, \\
\mathrm{~mm}\end{array}$ & $\begin{array}{c}M, \\
\mathrm{~mm}\end{array}$ & $\begin{array}{c}a, \\
\mathrm{~mm}\end{array}$ & $\begin{array}{c}w, \\
\mathrm{~g}\end{array}$ \\
\hline $\mathrm{A}$ & 45 & 30 & 17.2 & 2.8 & 2.8 & 8.4 & 3.19 & 3.99 & 30 & 109 \\
\hline $\mathrm{B}$ & 45 & 30 & 17.2 & 2.8 & 5.6 & 14.0 & 3.19 & 3.99 & 30 & 112 \\
\hline $\mathrm{C}$ & 45 & 30 & 17.2 & 2.8 & 8.4 & 19.6 & 3.19 & 3.99 & 30 & 115 \\
\hline
\end{tabular}

All mechanical tests in the current study were performed by a SANTAM testing machine with axial actuators. The SANTAM has a static capacity of $150 \mathrm{kN}$, with a maximum stroke of $300 \mathrm{~mm}$. A constant displacement rate of $0.5 \mathrm{~mm} / \mathrm{min}$ of the movable head of the testing machine was applied to all types of mechanical tests.

Single lap's flatwise compressive tests were conducted on the lattice core panels in accordance with the standard test for sandwich core material. Flatwise compression tests were performed according to the ASTM C365 test standard [29].

For the flatwise compression test, the specimens with an area of $90 \times 90 \mathrm{~mm}$ were put on a self-aligning spherical bearing block. Figure 6 shows the specimen mounted on the testing machine. 


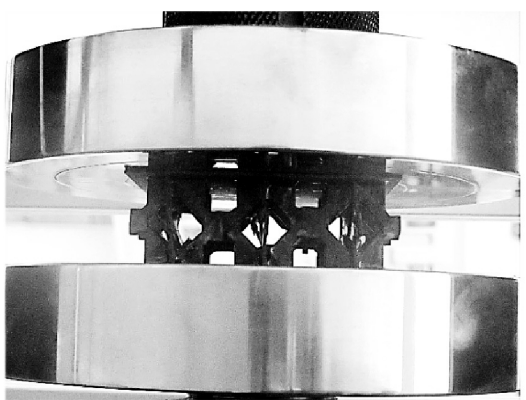

a

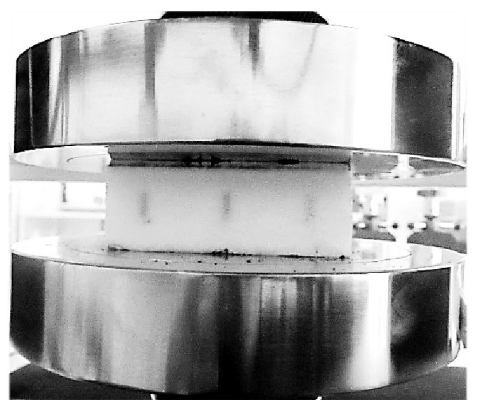

$\mathrm{b}$

Fig. 6. Flatwise compression test setup: unfilled (a) and foam-filed (b) specimens.

\section{Results and Discussion.}

3.1. Comparison of Foam-Filled and Unfilled Specimens. The force-extension curve of polyurethane foam has been shown in Fig. 7.

Different areas are specified by $A, B, C$, and $O$ points. The $O A$ area identifies the linear response of the foam and its elastic deformation, which is due to the foam bended cell wall. The $A B$ area is related to a near-plateau tension area, the foam decreasing stability and the start of a severe congestion inside the cell, which is followed by poor response to the tolerance of applied load. Hence the near-plateau was created. This trend continues until the densification area. Thus, the cells were compressed, the force was increased, and placed into $B C$ location with a slight deformation. Then, the foam-filled specimen was investigated under pressure force. The force-extension curves for A, B, and C specimens filled with polyurethane foam and unfilled specimens were constructed (Fig. 8a-c), respectively.

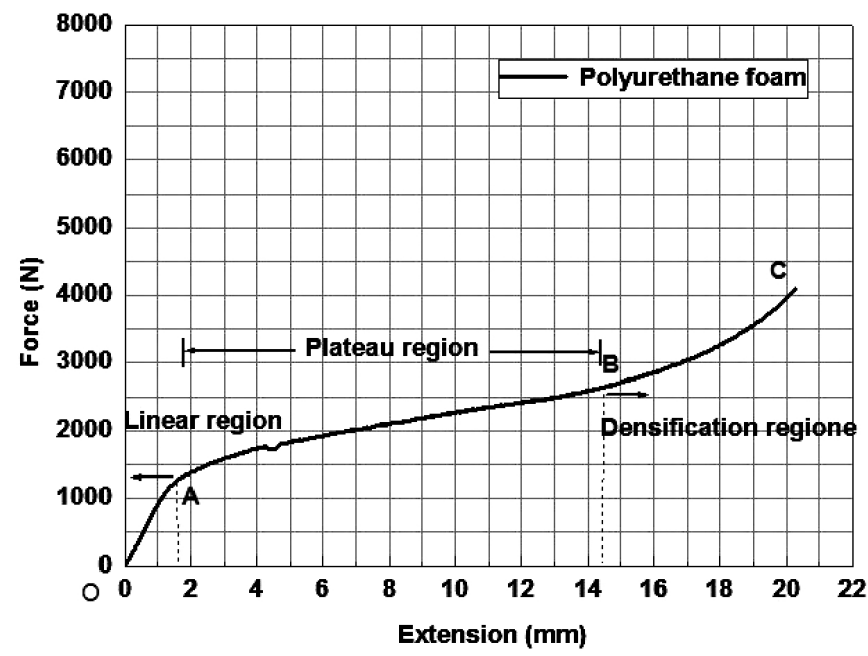

Fig. 7. Compressive force-extension curves for the polyurethane foam.

In order to determine the contribution of polyurethane materials, the curves related to the sandwich panels specimens with honeycomb cores and polyurethane blocks were added to shapes during the loading period (or loading phase). A similar trend or behavior with a higher loading peak and stable in unfilled specimens was observed after the survey of the behavior of filling sandwich panels. Similar patterns such as the first peak region, flat area, and the region of load increase in densification can be found in all curves. The load 
Flatwise Compression Strength and Energy Absorption ...

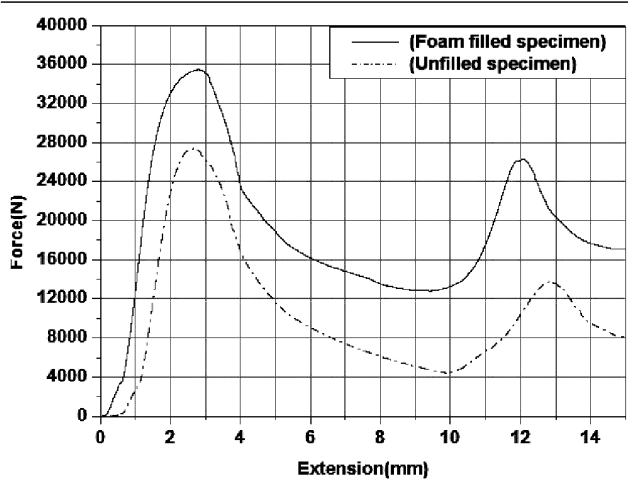

a

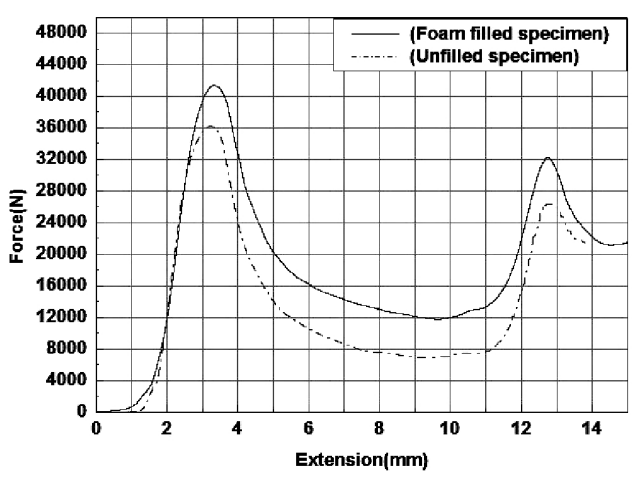

b

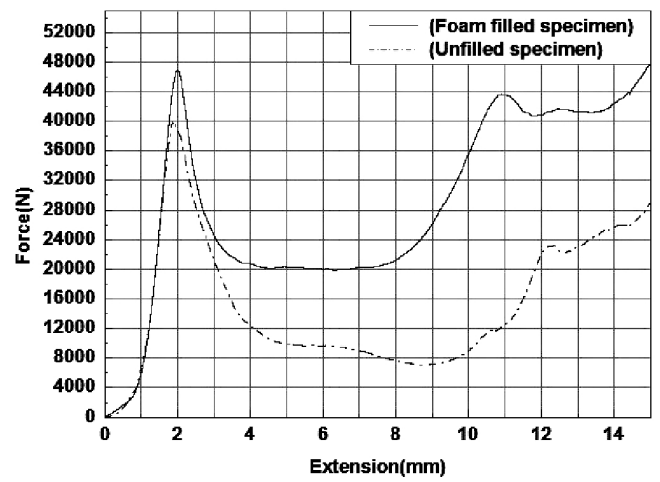

C

Fig. 8. The response of foam-filled and unfilled specimens: (a) specimen A; (b) specimen B; (c) specimen $\mathrm{C}$.
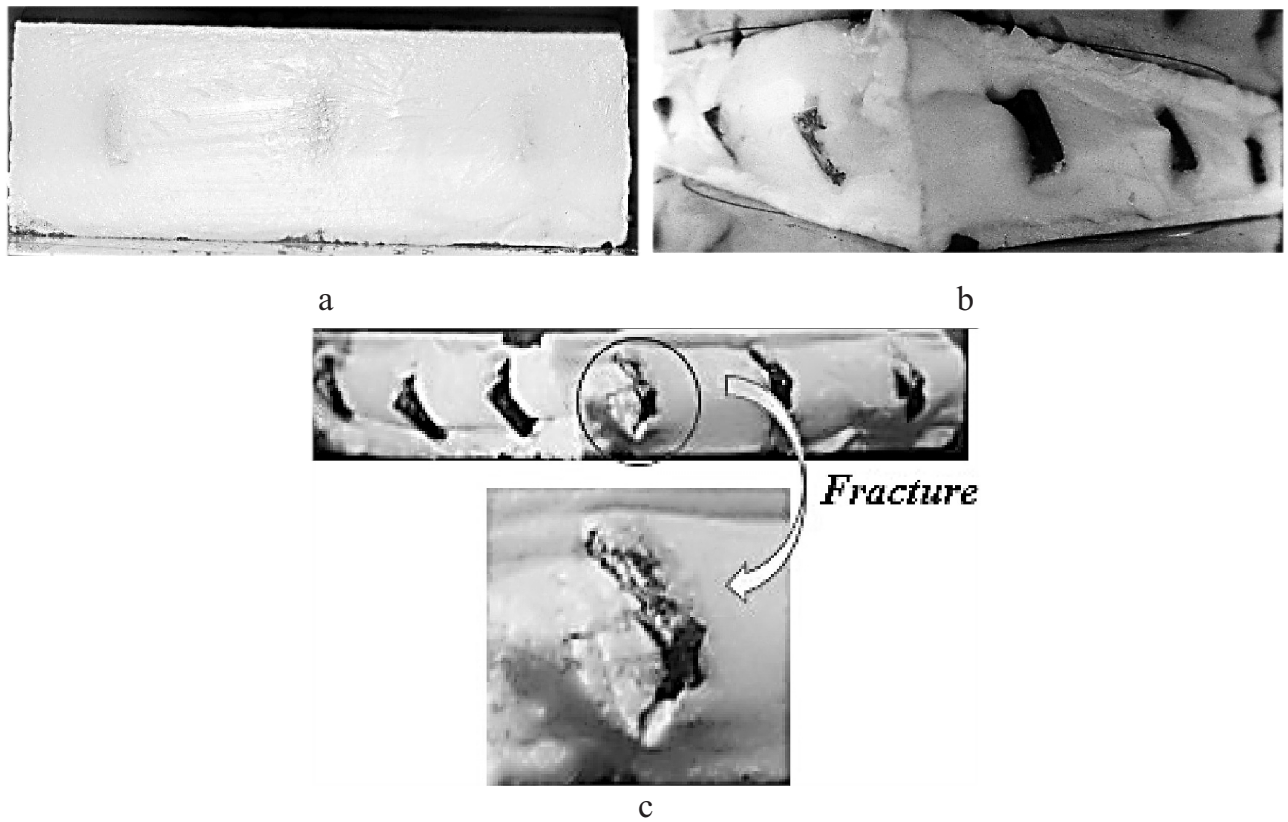

Fig. 9. The response of foam-filled specimen B in quasistatic compression tests: (a) displacement $D h=0$; (b) displacement $D h=5 \mathrm{~mm}$; (c) displacement $D h=10 \mathrm{~mm}$. 
response was linear during the first steps of loading and the contribution of polyurethane foam to the increased final load at the first peak point was tangential and limited to the parts of lattice cores. The comparison between filled and unfilled specimens showed approximately a $20 \%$ progress in the load peak. This is due to the fact that the filled foams tend to rotational motion within the lattice parts, which are able of preventing the early buckle. Upon inspection of the failed specimens, shear deformation and foam crack are observed, as shown in Fig. 9.

The increased density of polyurethane foam elevated the load tolerance. It is observed that the total load response of filled specimens was greater than the sum of unfilled and block foam specimens. This increased load difference was shown at the shaded area in A, $\mathrm{B}$, and $\mathrm{C}$ specimens (Fig. 10a-c). According to the results of the present study, it is assumed that the load response of the foam-filled specimen is not linear with respect to the individual response of the unfilled specimen and the filled material. This synergistic effect may be due to the filled material, which can provide additional constraint to the lattice parts, which increases the buckling load value and adds the postbuckling stiffness.

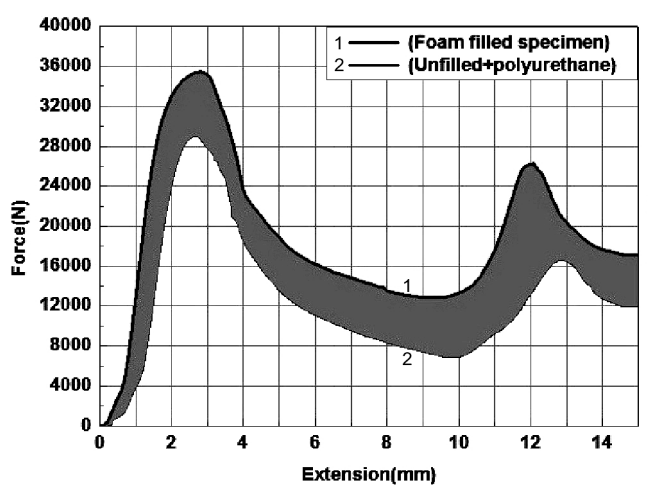

a

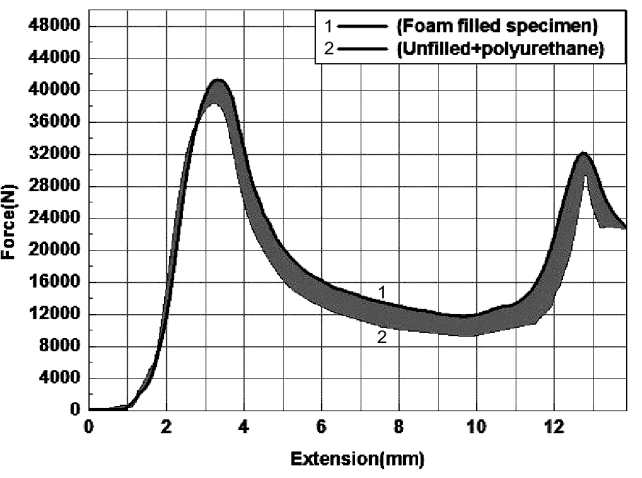

b

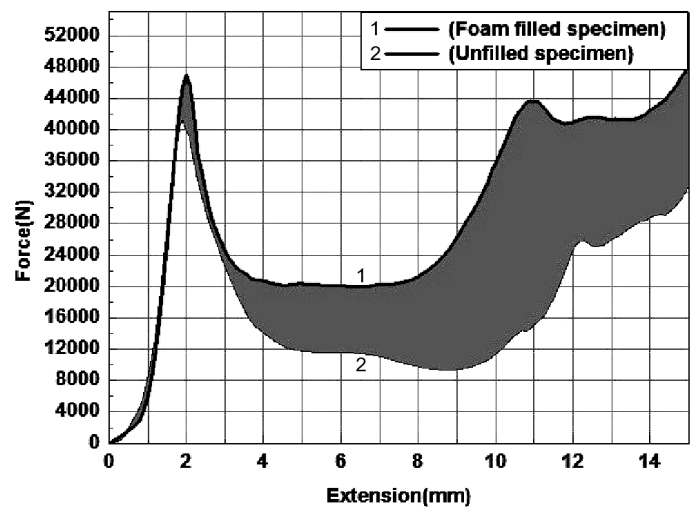

c

Fig. 10. The load response of foam-filled sandwich specimens and that of the polyurethane added to the unfilled specimens: (a) specimen A; (b) specimen B; (c) specimen C. (The shaded portion indicates the synergy observed during tests.)

Although the load response is a common method to evaluate the effects of filled polyurethane block as it is directly related to the load-carrying capacity, it can be noted that the energy absorption efficiency is a suitable way to quantify this enhancement effect. In this procedure, the influence of added weight is also considered. The comparative 
performance of energy absorption efficiency for the filled and unfilled specimens and the sum of the unfilled specimen and the filled foam is given in Fig. 11, which is calculated based on the load response in Fig. 8. According to the findings of this experiment, the energy absorption efficiency of filled composite panels improves as the compressive strain increases.

In Fig. 11a, it is shown that the enhancement effect of the foam for the sandwich panel is balanced nearly by the added weight when the compressive strain arrives at 0.1 . Consequently, the foam filled specimen has the highest energy absorption, the next is the unfilled specimen, and the lowest is the sum of the unfilled specimen and the foam. From Fig. 11b and c, one can observe that the energy absorption efficiency of foam-filled specimen is slightly higher than that of the unfilled one when the compressive strain is less than 0.1 , but it is superior when the compressive strain attains 0.11 , which superiority becomes more manifested with the strain increase. This can be explained by the fact that the enhancement effect of the filled foam is marginal when the compressive strain is small as mentioned above, as the strain increase, and the performance of the filled foam overcomes the disadvantage of the added weight. In comparison with Fig. 11a-c, it seems that the filled foam for the energy absorption efficiency of the low density core is positive. It attributes to the fact that the influence of the added weight from the filled foams is weaker than the enhancement effect for the lattice parts with a low-density core.

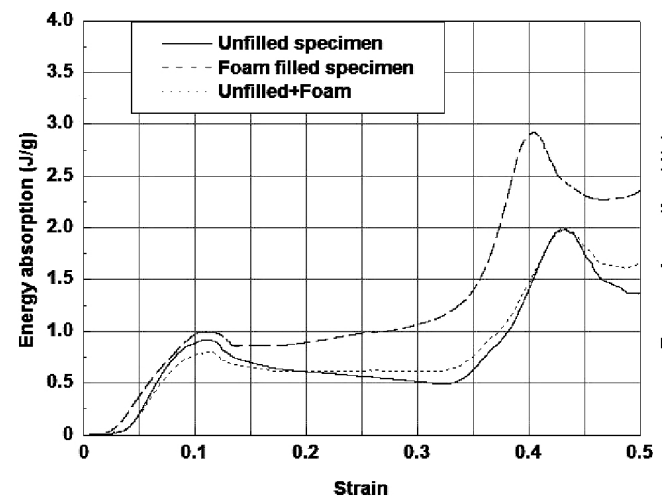

a

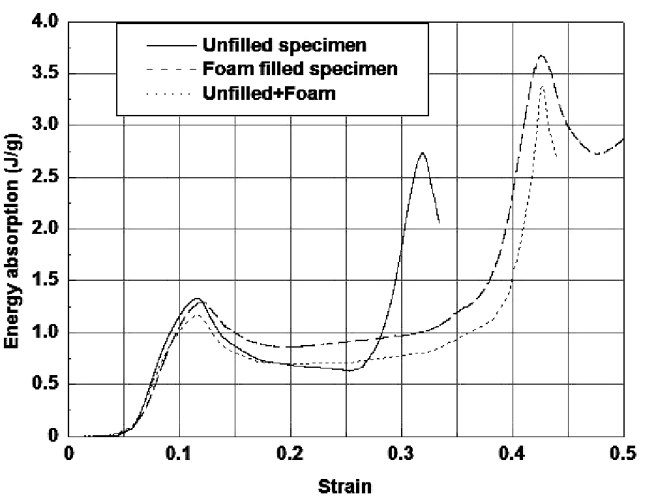

b

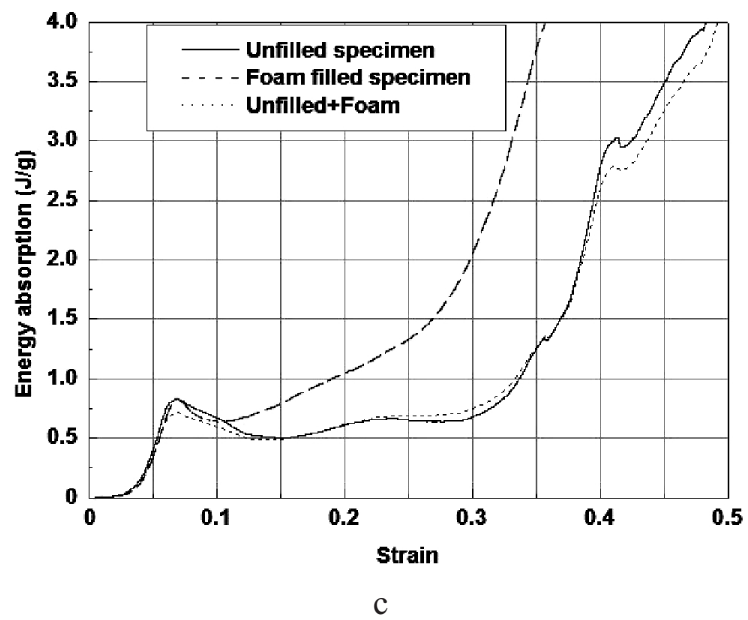

Fig. 11. Energy absorption efficiency of the foam-filled and unfilled specimens vs. that of polyurethane added to unfilled specimens: (a) specimen A; (b) specimen B; (c) specimen C. 


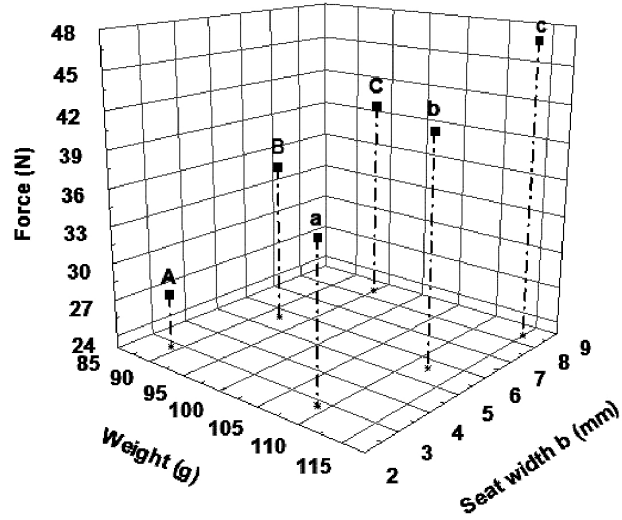

Fig. 12. The strength-weight dependencies of foam-filled and unfilled specimens.

3.2. Weight-Strength Ratios of Foam-Filled and Unfilled Specimens. The weightload dependencies of foam-filled and unfilled specimens shown in Fig. 12 imply an interesting pattern. With a slight increase in weight, the strength was improved by approximately $20 \%$, which is directly related to the foam density: the increase in foam density resulted in the strength improvement. Moreover, the most important issue, which should be considered during the product processing, is that the main reason for application of foam is its low weight.

Conclusions. In the present study, the responses of lattice core sandwich panels filled with polyurethane foam under compressive load were investigated. The compression tests indicate a synergistic effect: the foam-filled sandwich panels have a higher load-carrying capacity as compared to the sum of the unfilled specimens and the filled polyurethane block, which is due to the lateral support to the lattice parts provided by the filled foam. The energy absorption efficiency of the foam-filled sandwich panels with higher relative density (5.1 and 5.7\%) cores is lower than that of unfilled specimens when the compressive strain was small, as a result of the added weight. However, it is superior when the compressive strain attains about 0.1 , and the superiority enlarges with the strain increase. Nevertheless, the energy absorption of foam-filled sandwich panels with a lower relative density $(4.43 \%)$ lattice cores was superior to the unfilled specimens since the influence of the added weight was weaker than the enhancement effect produced by the filled polyurethane foam. This research was a primary attempt of using filled materials to enhance the energy absorption performance of lattice core sandwich panels.. The authors envisage further studies on filling different lightweight materials into low-density lattice core sandwich panels to improve their energy absorption capacity.

\section{Резюме}

Досліджено вплив наповнювача з поліуретанової піни на міцність і енергопоглинання комірчастих багатошарових панелей при стиску. Випробування на стиск показують, що несівна здатність комірчастих багатошарових панелей з наповнювачем, що складаються із поліуретанової піни вища, ніж панелей без наповнювача, або зразків тільки 3 поліуретанової піни. Ефективність енергопоглинання зразків із більш високою відносною щільністю комірок (5,1 і 5,7\%) є нижчою, аніж зразків без наповнювача за низьких рівнів деформації стиску, однак при досягненні останньою рівня 0,1 і вище має місце чітко виражений зворотний ефект. При цьому енергопоглинання зразків із меншою відносною щільністю комірок $(4,43 \%)$ вище, аніж зразків без наповнювача. 
1. L. J. Gibson and M. F. Ashby, Cellular Solids: Structure and Properties, Cambridge University Press (1997).

2. Y. Hirose, H. Matsuda, G. Matsubara, et al., "Proposal of the concept of splice-type arrester for foam core sandwich panels," Compos. Part A-Appl. S., 43, No. 8, 1318-1325 (2012).

3. Y. Rostamiyan, A. B. Fereidoon, A. Omrani, and D. D. Ganji, "Preparation, modeling, and optimization of mechanical properties of epoxy/HIPS/silica hybrid nanocomposite using combination of central composite design and genetic algorithm. Part 2. Studies on flexural, compression, and impact strength," Strength Mater., 45, No. 6, 703-715 (2013).

4. Y. Rostamiyan and A. B. Fereidoon, "Preparation, modeling, and optimization of mechanical properties of epoxy/HIPS/silica hybrid nanocomposite using combination of central composite design and genetic algorithm. Part 1. Study of damping and tensile strengths," Strength Mater., 45, No. 5, 619-634 (2013).

5. C. C. Foo, G. B. Chai, and L. K. Seah, "A model to predict low-velocity impact response and damage in sandwich composites," Compos. Sci. Technol., 68, No. 6, 1348-1356 (2008).

6. A. Ajdari, H. Nayeb-Hashemi, and A. Vaziri, "Dynamic crushing and energy absorption of regular, irregular and functionally graded cellular structures," Int. J. Solids Struct., 48, Nos. 3-4, 506-516 (2011).

7. H. Bart-Smith, J. W. Hutchinson, andA. G. Evans, "Measurement and analysis of the structural performance of cellular metal sandwich construction," Int. J. Mech. Sci., 43, No. 8, 1945-1963 (2001).

8. H. Fan, Q. Zhou, W. Yang, and Z. Jingjing, "An experiment study on the failure mechanisms of woven textile sandwich panels under quasi-static loading," Compos. Part B - Eng., 41, No. 8, 686-692 (2010).

9. A. Levy, J. Kratz, and P. Hubert, "Air evacuation during vacuum bag only prepreg processing of honeycomb sandwich structures: In-plane air extraction prior to cure," Compos. Part A - Appl. S., 68, 365-376 (2015).

10. S. Shi, Z. Sun, X. Hu, and H. Chen, "Carbon-fiber and aluminum-honeycomb sandwich composites with and without Kevlar-fiber interfacial toughening," Compos. Part A - Appl. S., 67, 102-110 (2014).

11. S. Rao, R. Das, and D. Bhattacharyya, "Investigation of bond strength and energy absorption capabilities in recyclable sandwich panels," Compos. Part A-Appl. S., 45, 6-13 (2013).

12. J. Kratz and P. Hubert, "Anisotropic air permeability in out-of-autoclave prepregs: Effect on honeycomb panel evacuation prior to cure," Compos. Part A-Appl. S., 49, 179-191 (2013).

13. B. Wang, L. Wu, L. Ma, et al., "Mechanical behavior of the sandwich structures with carbon fiber-reinforced pyramidal lattice truss core," Mater. Design, 31, No. 5, 2659-2663 (2010).

14. L. Liu, H. Wang, and Z. Guan, "Experimental and numerical study on the mechanical response of Nomex honeycomb core under transverse loading," Compos. Struct., 121, 304-314 (2015).

15. R. Roy, S.-J. Park, J.-H. Kweon, and J.-H. Choi, "Characterization of Nomex honeycomb core constituent material mechanical properties," Compos. Struct., 117, 255-266 (2014). 
16. A. Karakoç and J. Freund, "Experimental studies on mechanical properties of cellular structures using Nomex ${ }^{\circledR}$ honeycomb cores," Compos. Struct., 94, No. 6, 2017-2024 (2012).

17. C. J. Yungwirth, D. D. Radford, M. Aronson, and H. N. G. Wadley, "Experiment assessment of the ballistic response of composite pyramidal lattice truss structures," Compos. Part B - Eng., 39, No. 3, 556-569 (2008).

18. J. Xiong, L. Ma, L. Wu, et al., "Fabrication and crushing behavior of low density carbon fiber composite pyramidal truss structures," Compos. Struct., 92, No. 11, 2695-2702 (2010).

19. J.-H. Lim and K.-J. Kang, "Mechanical behavior of sandwich panels with tetrahedral and Kagome truss cores fabricated from wires," Int. J. Solids Struct., 43, No. 17, 5228-5246 (2006).

20. V. Deshpande and N. Fleck, "Collapse of truss core sandwich beams in 3-point bending," Int. J. Solids Struct., 38, Nos. 36-37, 6275-6305 (2001).

21. V. S. Deshpande and N. A. Fleck, "Energy absorption of an egg-box material," J. Mech. Phys. Solids, 51, No. 1, 187-208 (2003).

22. A. G. Hanssen, M. Langseth, and O. S. Hopperstad, "Optimum design for energy absorption of square aluminium columns with aluminium foam filler," Int. J. Mech. Sci., 43, No. 1, 153-176 (2001).

23. A. M. Harte, N. A. Fleck, and M. F. Ashby, "Sandwich panel design using aluminum alloy foam," Adv. Eng. Mater., 2, No. 4, 219-222 (2000).

24. J. W. Hutchinson and M. Y. He, "Buckling of cylindrical sandwich shells with metal foam cores," Int. J. Solids Struct., 37, Nos. 46-47, 6777-6794 (2000).

25. J. H. Kim, Y. S. Lee, B. J. Park, and D. H. Kim, "Evaluation of durability and strength of stitched foam-cored sandwich structures," Compos. Struct., 47, Nos. 1-4, 543-550 (1999).

26. R. J. D'Mello and A. M. Waas, "Synergistic energy absorption in the axial crush response of filled circular cell honeycombs," Compos. Struct., 94, No. 5, 1669-1676 (2012).

27. F. Tarlochan, S. Ramesh, and S. Harpreet, "Advanced composite sandwich structure design for energy absorption applications: Blast protection and crashworthiness," Compos. Part B - Eng., 43, No. 5, 2198-2208 (2012).

28. S. H. Yoo and S. H. Chang, "An experimental study on energy absorbing structures made of fabric composites," Compos. Struct., 86, No. 1, 211-219 (2008).

29. ASTM C365-00. Standard Test Method for Flatwise Compressive Properties of Sandwich Cores, ASTM International, West Conshohocken, PA (2000). 